\title{
Tarhana Soup in Turkey: Preparation and Service
}

ISSN: 2637-7659

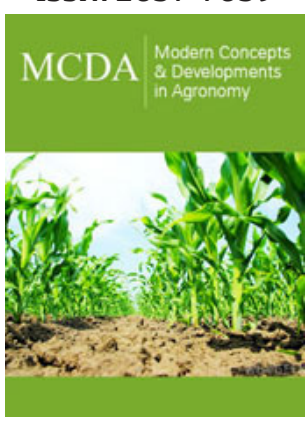

*Corresponding author: Hasan Özçelik, Süleyman Demirel University, Faculty of Science and Arts, Department of Biology, Isparta, Turkey

Submission: 柴 October 18, 2021

Published: 監October 27, 2021

Volume 9 - Issue 4

How to cite this article: Hasan Özçelik*. Tarhana Soup in Turkey: Preparation and Service. Mod Concep Dev Agrono. 9(4). MCDA. 000719. 2021. DOI: 10.31031/MCDA.2021.09.000719

Copyright@ Hasan Özçelik. This article is distributed under the terms of the Creative Commons Attribution 4.0 International License, which permits unrestricted use and redistribution provided that the original author and source are credited.

\section{Hasan Özçelik*}

Süleyman Demirel University, Faculty of Science and Arts, Department of Biology, Isparta, Turkey

\begin{abstract}
In this article, preparation types of Tarhana according to the regions in Turkey and 9 important varieties are tried to be explained. Main materials; yogurt or Kurut, wheat flour or cracked wheat, chickpeas, lentils, garlic, tomatoes, mint, red pepper, green pepper, salt and butter. If desired, sour plum, cranberry fruit, tarhana herb, dried meat and sugar beet, onion, garlic, tomato paste, hot pepper can also be added. It is widely believed that it takes its name from the word 'Darhane in Turkish', that is, weak economic power. Tarhana; it is the oldest and well-known soup in Turkish cuisine. There is no region or town in Turkey that does not produce and consume Tarhana. It is a flavored soup with a high nutritive rate and energy, prepared by drying, with a long shelf life. Its material is easily available and serviceable. With these features, it had been a reason for preference among nomadic Turks and has been made developed over time. The spice in Tarhana has an antiseptic and relaxing effect. It is a protein-rich, balanced and healthy food. Those who live in cold climates, rural areas and nomadic life; The slightly spicy one is an ideal food for the elderly and the sick. Southeastern Anatolia region prefers spicy.
\end{abstract}

Tarhana is known throughout the Ottoman geography. It is known and loved in a wide geography such as Anatolia, the Balkans, North Africa and Central Asia. How it is prepared; It varies according to the possibilities, climate, culture of the geography where it is produced and the skill of the person who prepared it. There are varieties such as Sour Tarhana, Sweet Tarhana, Flour Tarhana, Göce Tarhana, Tooth Tarhana, Cranberry Tarhana, Red and White Tarhana. Red Tarhana, Göce Tarhana, Tooth Tarhana and Flour Tarhana are the most common. Its production and consumption is high in the provinces of Ușak, Muğla, Antalya, Isparta, Afyonkarahisar, Edirne, Van, Malatya and Kahramanmaraș. Recently, industrial production for instant soup has been started. However, we do not have numerical information about the amount of production and consumption.

Keywords: Tarhana; Gastronomy; Kurut; Functional food; Cracked wheat; Fermentation

\section{Introduction}

There are two important opinions about the origin of the name 'Tarhana': It is thought that it comes from the words 'terhāne, Tarhune, Tarine' in Persian and has become Turkish over time. According to Güler and Konar (1999); In the dictionary called Dîvan-u Lûgatî'tTürk, which was written in the $11^{\text {th }}$ century, the word "Tar" was used for "tarhana", meaning "yogurt" that was kept for cold winter days from the summer season. It is accepted that this culture came to Anatolia from Central Asia with the Anatolian Seljuks [1,2]. Turks came to Anatolia via Iran and preferred Persian in scientific works at that time. In other words, the Turks discovered this food for the first time, but gave its name from Persian in accordance with the conditions of the period.

The Emergence of Tarhana: "One day, the Ottoman Sultan and state officials go on a campaign. Probably this person is Yavuz Sultan Selim and the expedition is to Iran or Aegypt. During the journey, they become guests of a nomadic oba (highland house). Oba's lady does not have much to offer, so she prepares a soup with meager means and offers it to her guests. After offering the soup, she was ashamed and bored with the Sultan and said, "My Sultan; narrow household soup, I will offer you more; enjoy it" she says. Sultan does not embarrass the woman, he says that he likes the soup very much. He orders his companions to make this soup in the Palace as well. Thus, the soup called "darhane" began to be called "Tarhana" over time [2]. Tarhana had been later recognized, loved, produced and consumed throughout the Ottoman geography (Figures $1 \& 2$ ). 


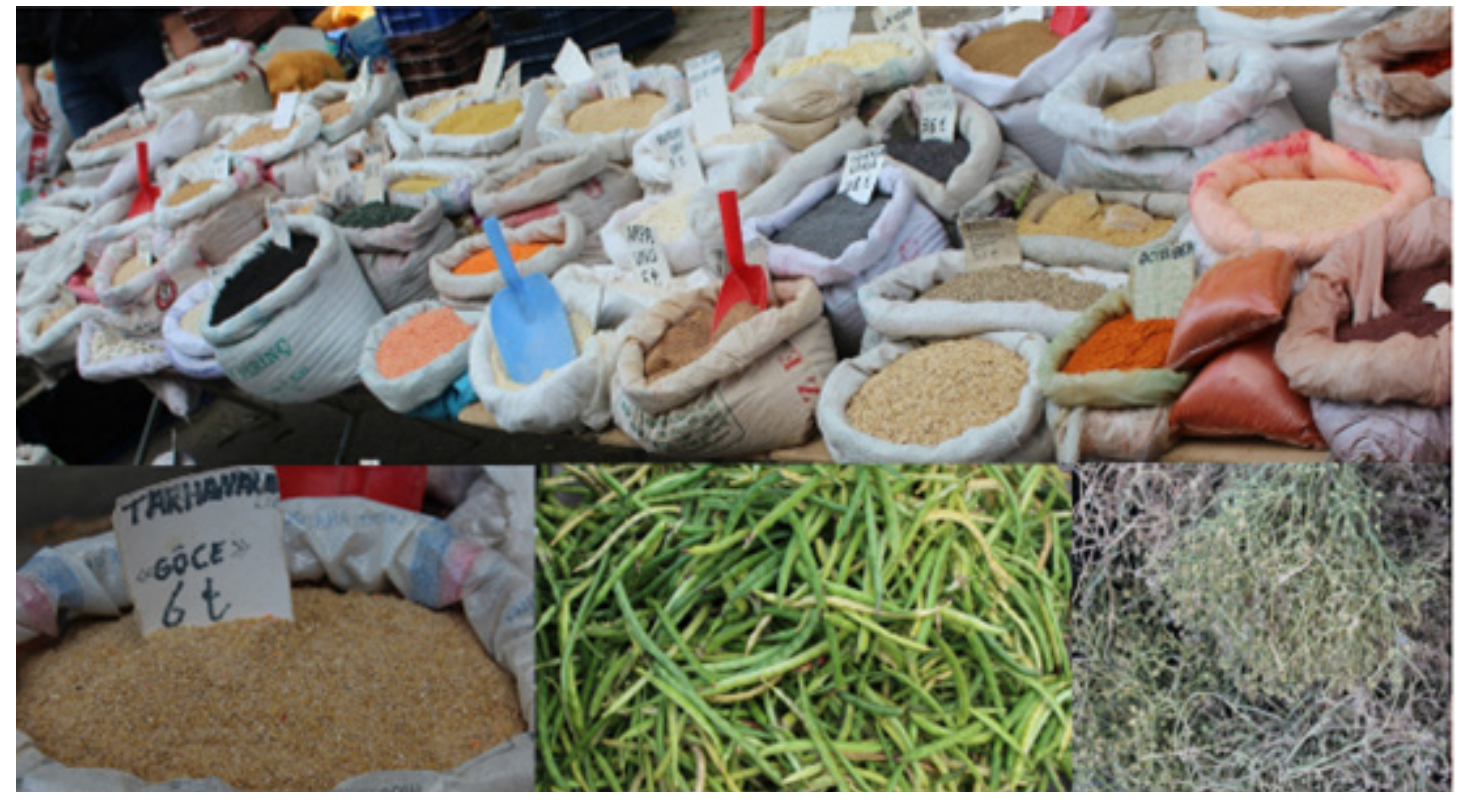

Figure 1: Herbal materials used in the production of tarhana and the sale of dried Tarhana in the public market (Isparta).
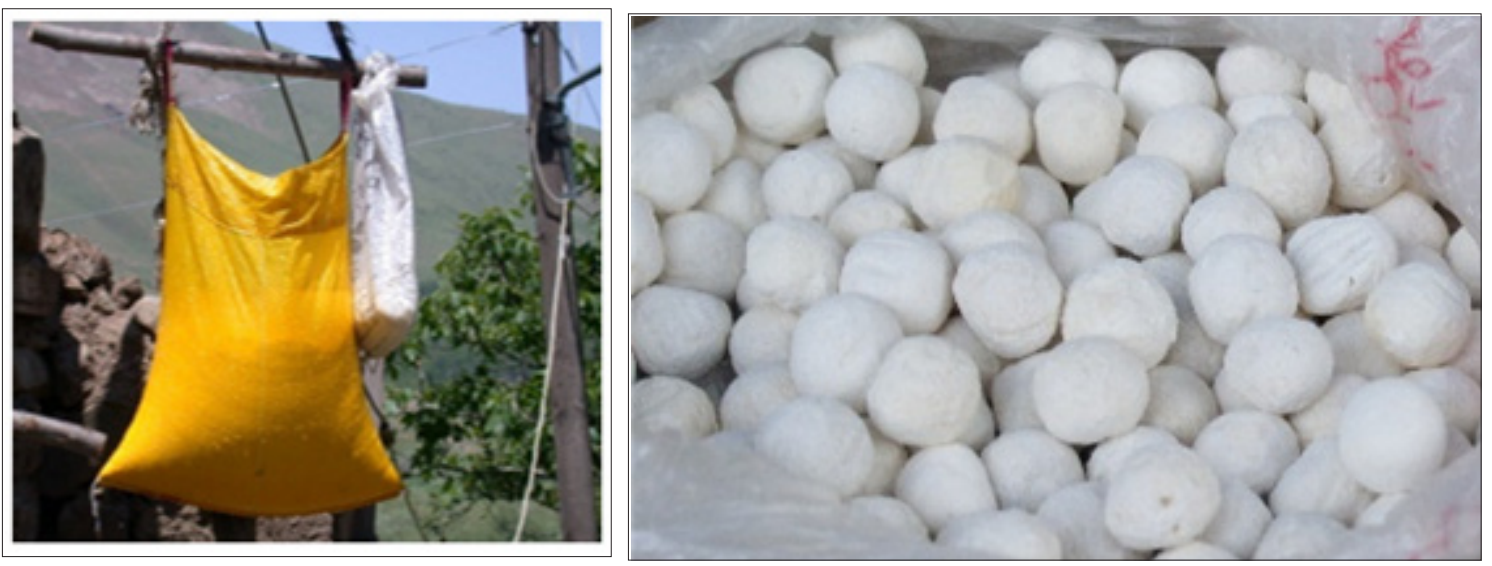

Figure 2: Preparation of Kurut, which is used instead of strained yogurt in the production of Tarhana (Van).

Tarhana; It is light in weight, has high nutritional value, keeps the stomach full, and is suitable for practical consumption. It is durable enough not to deteriorate in heat and cold. Due to these features, it became an important food of the Ottoman Army. The first known production in the palace was made by the mother of Yavuz Sultan Selim.

From Kahramanmaraș, II. Gülbahar Hatun (mother the Yavuz) is cooking at the palace by mixing plenty of yogurt with wheat crackers.

She sweeten with thyme and salt. After the resulting paste she has cooled, she dried in the sun it. This dry food obtained is Tarhana. Over time, its material and preparation were changed and improved. However, Maraş Tarhana is still produced by this method.
Official procedures continue for Göce Tarhana produced in Muğla and Afyonkarahisar, Cranberry Tarhana produced in Bolu, and Cranberry Tarhana produced in Kütahya; Uşak Tarhana; For Maraş Tarhanası, registration and geographical indication certificaties were obtained by the Turkish Patent and Trademark Office [2].

Except for magazine type information about tarhana [1-3], no scientific study was found. It is hoped that the introduction of such an important type of food will make an important contribution to Turkish culinary culture and humanity. In the article; information about tarhana varieties in Turkey, their names, raw materials used in production, production methods, preparation for service, regions where it is made and its commercial value are given. 


\section{Material and Method}

The essence of the study is based on the experiences of tarhana producers and our observations on these productions. The study is an ethnobotanical study. For this purpose, people who produce Tarhana in various regions of Turkey were interviewed, interviews were held during its production, notes were taken and photographs were taken of their products. All findings were made into a report. It was a work that takes about 10 years. The plants mentioned in the article and their Latin names are as follows: Tarhana herb (Çördük other Turkish name): Echinophora tenuifolia, Garlic: Allium sativum, Onion: Allium cepa, Mint: Mentha x piperita, Thyme: Thymus/Origanum spp., Tomato: Lycopersicum esculentum, red/ green Pepper: Piper annuum, Black Pepper: Piper nigrum, Chickpea: Cicer arietinum, Kızllclk(Ergen other Turkish name): Cornus mas, wild sour Plum: Prunus divaricata, Wheat: Triticum vulgare, Rice: Oryza sativa, Cowpea: Vigna sinensis, Pistachio: Pistacia vera, dried Beans: Phaseolus vulgaris, red Lentils: Lens cullinaris, Sugar Beet: Beta vulgaris var. saccharifera, Chard: Beta vulgaris var. cicla and Spinach: Spinacia oleracea.

\section{Findings and Discussion}

Tarhana is known throughout the Ottoman geography. It is a type of soup that is known and loved in a wide geography such as Turkey, the Balkans, North Africa and Central Asia. The form and content of its preparation varies according to the opportunities, climate and culture of the produced geography where it is located. Sour Tarhana, Sweet Tarhana, Flour Tarhana, Göce Tarhana, Tooth Tarhana (it is also known as Top Tarhana, Koca Tarhana); Cranberry Tarhana, Red and White etc. There are varieties such as Dried and Fresh Tarhana. Red Tarhana, Göce Tarhana, Tooth Tarhana and Flour Tarhana are the most common. It is produced in the provinces of Ușak, Muğla, Antalya, Isparta, Konya, Afyonkarahisar, Edirne, Van, Malatya, Kahramanmaraș. It has recently started to be commercialized. Industrial production has been made for the purpose of instant soup. However, there is no information about its production, consumption and economic value. Because it is produced with traditional methods and for domestic needs.

\section{Common production method}

An important part of Tarhana consists of strained yogurt and wheat. Yoghurt, wheat flour/Yarma, dried mint/thyme and red pepper, green fresh pepper, onion are chopped and grated and mixed. It is placed in a container, covered with a clean cloth and left for 7-10 days to ferment. The waiting time can be increased. The one that is left to ferment for a long time is called 'Sour Tarhana'. If the waiting period does not exceed one week, it is called 'Dessert Tarhana'. This fermented material is poured onto a clean cloth. It is dried outdoors in a shady, airy place (Figures 3-5).
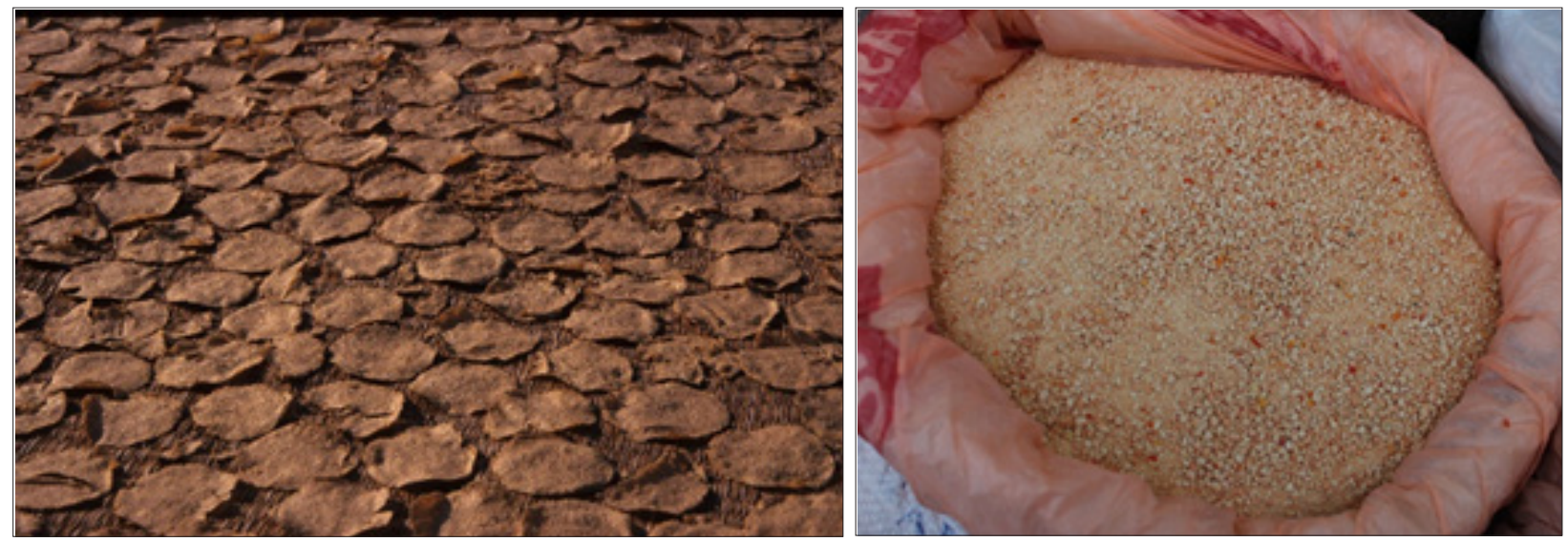

Figure 3: Sun drying of Tarhana in Eastern Anatolia (in left) and granulation by rubbing (in right).
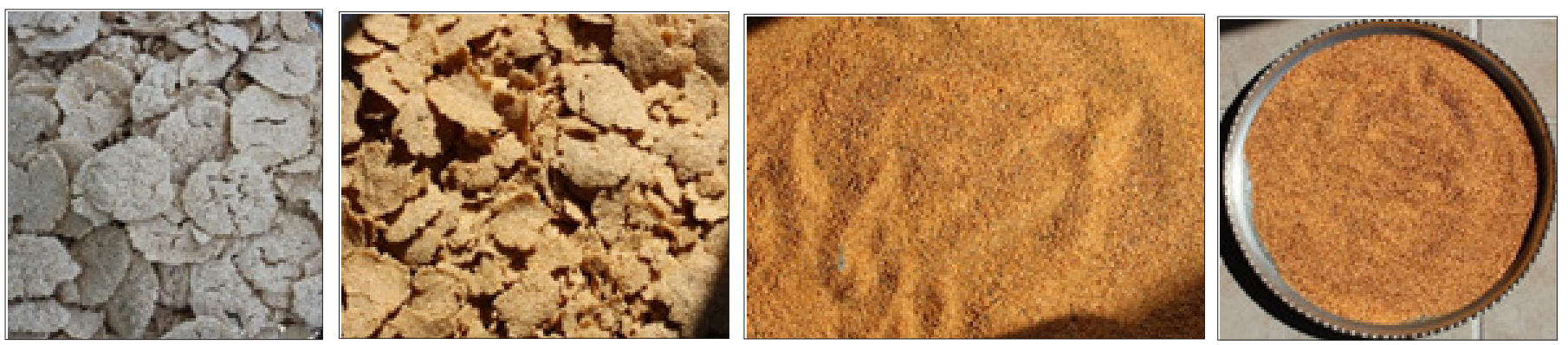

Figure 4: Koca (Tooth, Ball) Tarhana (in left) and Flour Tarhana (in right), prepared by the Taurus nomads. 


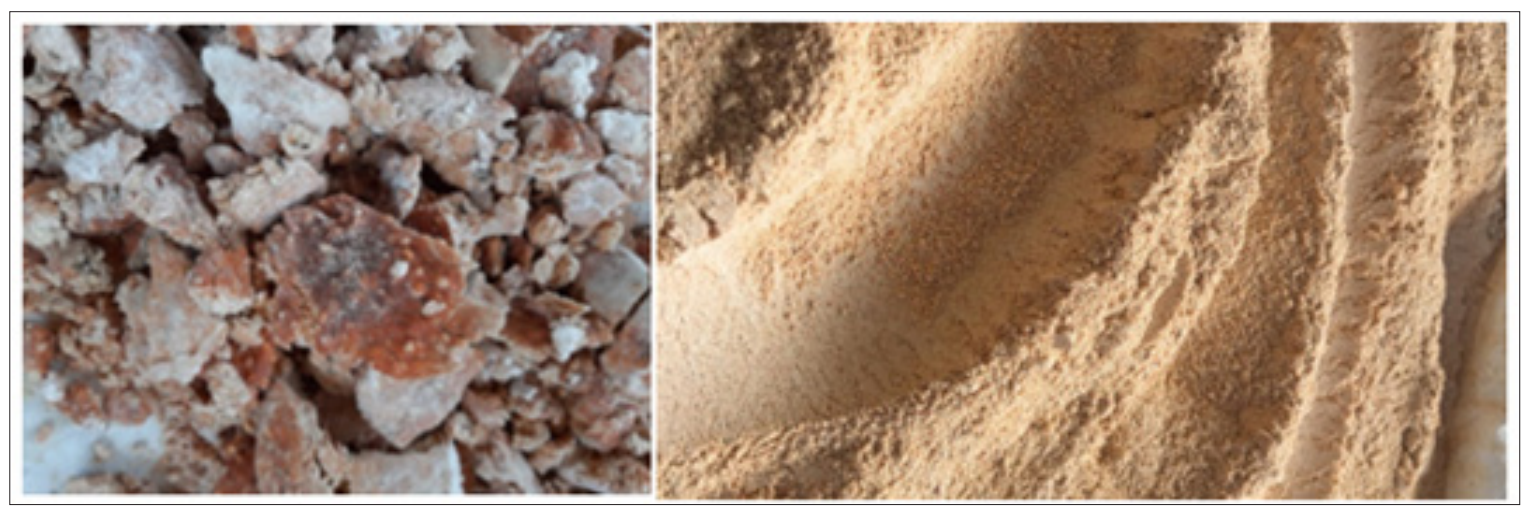

Figure 5: Göce Tarhana prepared by the Taurus nomads (Afyonkarahisar).

\section{Prepare the sauce}

A. Type 1: Finely chopped garlic, tomato paste or finely chopped tomatoes, pepper paste or finely chopped red pepper are fried in butter and added to the soup.

B. Type 2: Butter is melted in a pan, 2 teaspoons of dried mint are added to it and roasted. It is added to the soup and the soup is drunk. Optionally; Antep Pistachio powder can also be roasted while the butter is fried and poured over the soup.

\section{Preparation for serving}

Tarhana granules or balls should be mixed with water by adding water and stirring continuously until it boils in order for the dried Tarhana to dissolve. A little salt, garlic and spices can be added to taste. When the tarhana is completely melted in the pot, it is left to boil on its own. If the consistency is thick, some boiling water can be added. It can be served with pickles, mint, green pepper, radish, fresh grapes, tomatoes, by putting dried bread pieces in it.

\section{The preparation to dry of various types of Tarhana is explained below}

Malatya tarhana: It is made with rolled wheat, yoghurt, flour, bread yeast, salt.

Preparation: Wheat is boiled the day before. It is mixed with boiled wheat, yoghurt, flour, yeast and salt until homogeneity is achieved. The obtained product is filtered in cloth sacks for 3 days. During this time, it is expected to sour and ferment. Then, it is cut into small pieces in the thickness of the palm and laid on a clean surface and dried for 3-4 days. It is then collected and stored in cloth sacks to make soup in winter.

Uşak tarhana: It is known as 'flour tarhana' in Uşak. The skill of the producer is very important. It is made wheat flour, full-fat yogurt, green, red and hot peppers, onions, with tomatoes and mint. Preparation: $25 \mathrm{~kg}$ flour, $5 \mathrm{~kg}$ green, red, hot pepper, yoghurt, salt, mint, baker's yeast, onion and tomato are kneaded and left for 1 month. It is kneaded over and over again every day. It is fermented during this time. Then it is put on a clean cloth and dried in the shade. It is a granular tarhana variety that is reduced in size at regular intervals and dried in the shade. It is sieved from the sieve. It can be used by drying or it can be stored in the form of dough under refrigerator conditions or by freezing.

Flour tarhana: It is made with tomatoes, flour, strained yogurt, boiled chickpeas, green pepper, red pepper, salt and mint. Preparation: Chickpeas, red pepper, green pepper, tomato are boiled in the same pot. Chickpeas, peppers and tomatoes are passed through the robot (through a blender or perforated basin). Putting the yogurt in the pouch, mint, salt and flour are added and kneaded, the dough is made. It is kneaded and kept for 30 days. It is covered and kept in the shade. One month later, it is transferred spoon by spoon on a clean cloth and dried in the shade. It is rubbed and sieved by hand.

Preparation for serving: Before cooking, butter, tarhana and tomato paste are slightly roasted. Tarhana is crushed with cold water. It is mixed so that it does not clump. It is made download and service. Experience is required for its production, the amterials amount is adjusted by the experienced person. It is widely produced in the Mediterranean region. Tarhana price is around 60-80TL/ kg.

Bolu kızılcık tarhana: It is produced by mixing puree of Kızılcık tree fruits, wheat flour, kneading with iodized salt in certain proportions in the vicinity of Bolu. In order for the tarhana to be close to its pink-red color, it should be dried by laying it on a clean cloth in a sun-free environment.

Kütahya kızılcık tarhanası: The most important difference from Bolu Kizılcık Tarhana; in making is the cooking of cranberry puree. After cooking, wheat flour is added to the mash. It turns a pink-purple color when cooked. It has sour taste. It is produced commercially by local food enterprises. It is from the sour tarhana group.

Maraş tarhana: It is made with Wheat (split), Yogurt, and Water. Preparation: Wheat for wrought (for splitting) is sorted, washed and ground in a mill. The prepared half is cooked by stirring until it dissolves in boiling water. Then it is left to listen for 3-6 hours. 
This is called the 'Dövme aşı' in the region. It is cooled until it becomes warm. In the meantime, a large amount of yogurt is added to it. Yogurt and wheat are kneaded until a homogeneous mixture is obtained. It is left to ferment for 12-18 hours. This is also called 'Tarhanaşı'. The fermented meal is laid out on clean cloths and dried in the sun for 2-4 days in a moisture-free area.

The ways of consumption are as follows (in order of importance): It is made into soup and drunk. It is drunk by adding to hot meat or cooked head juice. It is eaten semi-dried. It is eaten dried like a cookie. It is eaten by frying in oil or by flaking on a hot plate. After soaking and absorbing water, it is fried in oil with onions and eaten.

Koca tarhana: This tarhana is also called Tooth Tarhana or Top Tarhana. It is made with $5 \mathrm{~kg}$ split wheat, $4 \mathrm{~kg}$ of strained yogurt, boiled chickpeas or beans, spices, kitchen salt. Preparation: Yogurt is crushed and whipped, put on the stove and heated, 1 tablespoon of kitchen salt is added and mixed. When it starts to boil, split wheat is added and mixed again. Boil for about 5 minutes until thickened. It is removed from the stove and rested for 5-6 hours to swell. When it cools down, it is compressed by hand as if kneading the dough, in a flat form the size of the palm of the hand; or rolled into walnut-sized round pieces and laid on a clean surface to dry.Preparation for serving: It is taken 5-6 pieces of tarhana pieces, put them in the pot, add water. 1 hapas (i.e. a large handful) of chickpeas or bean grains is added and boiled. It is added the spice that close to cooking, add red pepper and butter and take it off the stove. Onion is not added.

Göce tarhana: It is made with yoghurt $4 \mathrm{~kg}$, chicken eggs 5 pieces, wheat flour $4 \mathrm{~kg}$, red lentils $1 \mathrm{~kg}$, red pepper $4 \mathrm{~kg}$, semolina (sifted wheat flour, İrmik in Turkish) $1 \mathrm{~kg}$, broken rice $1 \mathrm{~kg}$, tomatoes $4 \mathrm{~kg}$, mint 1 bunch, parsley 1 bunch, onion $0.5 \mathrm{~kg}$, chickpeas $1 \mathrm{~kg}$, black pepper, salt, split (ie cracked wheat, Yarma in Turkish) 1kg, garlic approximately $250 \mathrm{~g}$. Preparation: Red pepper, tomato, onion and garlic are finely chopped and boiled in a deep pot for 0.5 hours. It is transfered to a larger pot to cool. It is passed through a blender (crumbled) to get a sauce consistency. Pre-boiled chickpeas, lentils and rice are added to the cooled sauce. It is mixed. Then flour, yoghurt, raw egg, cracked wheat, semolina, salt, black pepper, finely chopped parsley and mint are added and mixed. A soft, dense dough is made and covered. It is mixed daily. In between, a wake-up process, that is, mixing, is done with yogurt and milk 1-2 times. Flour is added according to the consistency. This process continues for 21 days. Then, flour is spread on a clean and dry cloth and transferred to tarhana. The next day, tarhana is turned upside down. Two days later it is cut into small pieces. After it dries well, it is ground to the consistency of flour in the mill and laid on a clean cloth again. It is dried again for a day or two. It is stored ready for consumption.

Preparation for serving: It is added olive oil to the soup pot, add a spoonful of tomato paste, fry it, add a teaspoon of dried mint. It is choped one or two cloves of garlic and add, fry for 2 or 3 minutes. 4 spoons of powdered tarhana is thickened in another bowl with cold water, then it is slowly brought together with tomato paste sauce. It is added 5 glasses of water to it. It is stired frequently to prevent it from sticking to the pan. It is cooked for 20-25 minutes.

Sour tarhana: It is made with sour plum, ayran, cracked wheat, sugar beet, butter, salt. Sour plum fruits are boiled, then filtered, their skins are distinguished. Ayran is used instead of water. Splitting (wheat is crushed in the mill) pulled for splitting. It is added $2 \mathrm{~kg}$ of sour plum fruit to $3 \mathrm{~kg}$ of splits. It is added with buttermilk or yogurt buttermilk. Mixed and boiled. After swelling, bite is made and spread. It is dried in the sun for several days. Preparation for serving: Some sour tarhana ingredients are put in a pot with water. It is stired while heating and stir until it boils. It is added sugar beet in small pieces. After the beet is cooked, it is served by adding oil and sauce.

\section{Conclusion and Suggestions}

Turks have been influenced by various civilizations throughout history and have had a rich gastronomic culture. Tarhana soup is also an important part of this rich food culture. Tarhana is usually prepared and served by women for domestic needs in Turkey. However, it has recently been industrialized and partially commercialized. Soups such as Yoghurt Soup (named in Kayseri; Toğga Soup), Yoghurt Yarma Soup, Yayla Soup, Ayran Așı are other soup types close to Tarhana.

Tarhana soup is very different from other soups. The reason for the rich food content; comes from the raw materials included in its structure. While rice soup, flour soup, mushroom soup, tomato soup, lentil soup are based on a specific food source, Tarhana soup is made from a wide variety of ingredients. Although it is a soup in terms of usage, it resembles a meal in terms of its content. Drying and splitting in the preparation of 'ayran aşı' (wheat for soup, Erzurum side calls it 'Gendime'). The mixture obtained by dissolving the cooked wheat and Kurut is boiled together. Then the sauce made with onions is added to this soup and served. Kurut, which is a durable type of yogurt, is a food that meets the need for yogurt in places where there is little or no milk in winter. A little more information should be given about Kurut, as it is used in the production of many foods.

It is estimated that during the migration of Turks from Central Asia to Anatolia, the composition of "Kurut" was enriched and turned into "Tarhana". 'Tarhana soup', which is used by Turks for nutritional purposes during long migration routes and war campaigns. It also met a very important need in the nutrition of the Mamluk, Seljuk and Ottoman armies; but it is understood that it was popularized by II. Gülbahar Hatun from the Ottoman palace cuisine.

Tarhana production has been improved over time and its composition has been changed. Using 'Kurut' instead of yogurt has become widespread in the Eastern Anatolia region and Central Asia countries. When yoghurt is dried, it has a long shelf life and is easy to use when desired. This is called 'Kurut'. $1 \mathrm{~kg}$ kurut is 
obtained by boiling from $15-17 \mathrm{~kg}$ of yoghurt or non-fat buttermilk. Its production varies by regions. 'Kurut' is known by different names in different regions. Although its most well-known name is 'Kurut', it is known as 'Keș' in Taurus people, 'Geșk' in Siirt, 'Keșk, Çörten, Torak, Terne' in Bingöl, 'Çortan' in Mardin, 'Keş, Çökelek' in Antalya. Its nutritional value is quite high. It contains rich amounts of important minerals such as animal protein, $\mathrm{Ca}, \mathrm{K}, \mathrm{P}$, which are necessary for a healthy life. The name Çördük otu (Echinophora tenuifolia) must have come from the name Çörten.

In the western regions of Turkey and on the Thrace side, tarhana soup is prepared using yoghurt in a pouch (strained yogurt), flour, tomatoes, onions, and tarhana herb (Echinophora tenuifolia), salt, and hot pepper as desired. No other additives are used.

For the production, cracked wheat(Yarma in Turkish) which is the basic raw material of tarhana production. For this, wheat is crushed in a mill, ground for splitting or pounded in a mortar. Strained yoghurt is obtained by adding fresh yoghurt to clean cloth bags and minimizing its water.

In today, a food with the name 'Tarhana' is not known in Central Asia. However, the production of 'Kurut', which means 'non-fat dry yogurt', added to Tarhana etc. is still being continued. At the same time, 'Kurut' is still produced as a culture of the nomadic people in the Eastern Anatolia region and is included in various food products [4]. 'Kurut' is a winter food additive, has a long shelf life, and is the most important component of foods such as 'Kelledoş meal, Tarhana soup'. 'Kurut' is a fermented dairy product made from yoghurt or buttermilk and can be stored for a long time [5]. It is a food culture of the nomadic Turks, which has been made since ancient times by straining and thickening the yogurt or kneading it with salt and oil/cream and drying it in the sun. The economic opportunities of these Turks are weak. They do not have a regular life. Most of their livelihoods depend on animal husbandry. Eastern and Southeastern Anatolia regions still maintain Turkish food culture originating from Central Asia and produce interesting foods [6]. Southeast provinces (Gaziantep, Kahramanmaraş, Diyarbakir, Siirt, Mardin etc.) are very famous for gastronomy. In Eastern Anatolia; Van, Bitlis, Erzurum and Hakkari provinces have an important culture in dairy products. The Western Anatolia region was influenced by Europe, but did not abandon its ancestral culture [7].

\section{Acknowledgement}

Many thanks to Fatmaana Özçelik (from Isparta), Fatma Cengiz, Şaziye Özçelik (from Antalya), İlkay Moran (from Afyonkarahisar) and Ayșe Özkal (from Uşak), who produced tarhana or gave information about how it is produced.

\section{References}

1. https://www.usaktayiz.com/tarhana-corbasinin-kokeni-nedir

2. https://tr.wikipedia.org/wiki/Tarhana_\%C3\%A7orbas\%C4\%B1

3. https://tarhana.com.tr/tarhana/tarhana-tarihsel-sureci

4. Özgökçe F, Özçelik H (2004) Ethnobotanical aspect of some taxa in East Anatolia (Turkey). Economic Botany 58(4): 697-704.

5. Özçelik H (1989) A study on the use of plants used in the preparation of dairy products in Van and its region (Van ve yöresinde süt mamüllerinin hazırlanmasında yararlanılan bitkilerin kullanılışları üzerine bir araștırma), TÜBITAK, DOĞA Türk Tarım ve Ormancllık Derg, 13(2): 356360 .

6. Ozgokce F, Yilmaz I (2002) Dye plants of East Anatolia region (Turkey). Economic Botany 57(4): 454-460.

7. Öztürk M, Özçelik H (1991) Useful plants of East Anatolia, SíSKAV Vakfı (Siirt), Semih Ofset ve Matb, Ankara, Turkey. 